\title{
Editorial
}

\section{Comunicado para socios y lectores}

\author{
Communication for partners and readers
}

\section{María Luisa López Salgado,* Juan José Trujillo Fandiño,* Alejandro Alonso Moctezuma*}

Con el enorme gusto de saludarte a través de esta nota editorial de nuestra revista, y siempre con el optimismo y la idea de que la situación del país y, por ende, de nuestra actividad profesional como Cirujanos Orales y Maxilofaciales tienda a mejorar día con día, es indispensable recordarte que no debemos bajar la guardia en ningún momento en los cuidados y medidas de protección que debemos seguir observando y hacerlos prácticamente costumbre para el ejercicio de nuestra profesión, sabedores de que este nuevo virus, así como otros que han aparecido, llegó para quedarse; a pesar de que ya la gran mayoría nos encontramos vacunados o inmunizados, sabemos que esa no es la protección total y de ahí el llamado a no bajar la guardia.
Me es grato comunicarte también que estamos ya en el proceso de la ampliación de la base de revisores para los artículos de nuestra revista, de tal manera que ya contamos con varios colegas que se han sumado a la tarea de revisar y evaluar todos y cada uno de los artículos que nos haces el enorme favor de enviar; recuerda que, como te lo he comentado, estamos en un proceso de cambio para darle un mayor peso a nuestra revista, no sólo en el ámbito nacional, sino también en el internacional, recordemos que con mucho orgullo nuestra revista es la más consultada en Latinoamérica y por eso queremos proyectarla aún más lejos.

Seguiremos trabajando en pro de nuestra asociación con el mismo entusiasmo con el que iniciamos, te envío un cordial y afectuoso saludo.

Comité editorial. 